WSRC-TR-2003-00445, Rev. 1

\title{
ELECTROCHEMICAL TESTS OF CARBON STEEL IN SIMULATED WASTE CONTAINING FENTON'S REAGENT (U)
}

\author{
PHILIP E. ZAPP AND JOHN I. MICKALONIS
}

SAVANNAH RIVER TECHNOLOGY CENTER

Publication Date: March 2004

Westinghouse Savannah River Company Savannah River Site Aiken, SC 29808 
This document was prepared in conjunction with work accomplished under Contract No. DE-AC09-96SR18500 with the U. S. Department of Energy.

\section{DISCLAIMER}

This report was prepared as an account of work sponsored by an agency of the United States Government. Neither the United States Government nor any agency thereof, nor any of their employees, makes any warranty, express or implied, or assumes any legal liability or responsibility for the accuracy, completeness, or usefulness of any information, apparatus, product or process disclosed, or represents that its use would not infringe privately owned rights. Reference herein to any specific commercial product, process or service by trade name, trademark, manufacturer, or otherwise does not necessarily constitute or imply its endorsement, recommendation, or favoring by the United States Government or any agency thereof. The views and opinions of authors expressed herein do not necessarily state or reflect those of the United States Government or any agency thereof.

This report has been reproduced directly from the best available copy.

Available for sale to the public, in paper, from: U.S. Department of Commerce, National Technical Information Service, 5285 Port Royal Road, Springfield, VA 22161, phone: (800) 553-6847, fax: (703) 605-6900

email: orders@ntis.fedworld.gov

online ordering: http://www.ntis.gov/help/index.asp

Available electronically at http://www.osti.gov/bridge

Available for a processing fee to U.S. Department of Energy and its contractors, in paper, from: U.S. Department of Energy, Office of Scientific and Technical Information, P.O. Box 62, Oak Ridge, TN 37831-0062,

phone: (865)576-8401,

fax: (865)576-5728

email: $\underline{\text { reports@ adonis.osti.gov }}$ 
This page was intentionally left blank 
WSRC-TR-2003-00445, Rev. 1

\section{ELECTROCHEMICAL TESTS OF CARBON STEEL IN SIMULATED WASTE CONTAINING FENTON'S REAGENT}

\section{SUMMARY}

Preliminary tests have been completed to assess the corrosivity of an in-tank process to decompose cesium and potassium tetraphenylborate in Tank $48 \mathrm{H}$. Testing was requested by the Tank 48 Closure Team to "Perform a corrosion study to assess the effects of reduced $\mathrm{pH}$ solution on Tank 48 components". ${ }^{1}$ The initial corrosion tests were in support of the Fenton's reagent process with ferric ion. ${ }^{2}$ A second set of tests was performed with tetraamido macrocylcic ligand in place of ferric ion. ${ }^{3,4}$ A task plan was approved prior to the start of the experiments, which prescribed short-term electrochemical testing to determine the corrosion susceptibility of carbon steel to simulated waste containing Fenton's reagent. ${ }^{5}$

Linear polarization resistance (LPR) and cyclic potentiodynamic polarization (CPP) tests were conducted on specimens of Type III waste tank steel, ASTM A537 class 1 in simulated waste solutions. The simulated waste also contained hydrogen peroxide and the catalysts ferric ion (Fenton's reagent) or tetraamido macrocylcic ligand (TAML ${ }^{\circledR}$ ). In the ferric ion tests run at $\mathrm{pH} 11$ and temperatures between 32 and $65^{\circ} \mathrm{C}$, a relatively low general corrosion rate of 5 mils per year ( 0.005 inches per year) was measured.

However, the general corrosion rate could exceed 100 mils per year $(0.10$ inches per year) as revealed in tests at $\mathrm{pH}$ 7. Pitting was observed on all but two specimens.

In the tests with the $\mathrm{TAML}^{\circledR}$ catalyst present, tests were completed at $\mathrm{pH} 9$ and 11 and at temperatures of 45 and $65^{\circ} \mathrm{C}$. The $\mathrm{pH} 11$ tests produced general corrosion rates of 1.7 to 7.6 mils per year ( 0.0017 to 0.0075 inches per year), similar to those measured with ferric ion at $\mathrm{pH} 11$. At $\mathrm{pH} 9$ the general corrosion rates that were measured in individual tests ranged from 2.1 to 36 mils per year. Pitting was observed also in these tests.

These experiments indicate that a decomposition process based on Fenton's reagent may not be excessively corrosive if performed at $\mathrm{pH} 11$. However, the LPR tests were performed under conditions that were not always at chemical equilibrium, as a result of the periodic additions of hydrogen peroxide and catalyst. To confirm these initial shortterm electrochemical test results, long-term (50 and 100 days' duration) coupon immersion tests are recommended. In addition to supplying accurate general corrosion rate data, coupon tests provide a means of quantifying the pitting susceptibility.

\section{INTRODUCTION}

WSRC plans to return Tank 48 to normal radioactive waste service in 2005. A prerequisite for this return is the removal from, or destruction in, Tank 48 of the organic compounds cesium and potassium tetraphenylborate (TPB). The TPB compounds are legacies of the former In-Tank Precipitation process, which was demonstrated in Tank 48 in 1983. A possible process to destroy the compounds is to do so in the tank itself with 
Fenton's reagent, along with other transition metal catalysts. Fenton's reagent is ironcatalyzed hydrogen peroxide, and it generates a reactive hydroxyl radical that is widely used to oxidize organic industrial wastes to carbon dioxide. Fenton's reagent is usually employed in acidic solutions, in the $\mathrm{pH}$ range 3 to 5 , which can aggressively corrode carbon steel. Waste tanks are typically operated at $\mathrm{pH}>13$, and often with $\mathrm{pH}>14$, where carbon steel is protected from general corrosion and localized corrosion modes such as pitting and stress corrosion cracking. Dilute waste with $\mathrm{pH}$ as low as 10.3 can be stored, as in Extended Sludge Processing, provided that the nitrite concentration exceeds a minimum value specified in the corrosion control program for the tank farm.

At the request of the Tank 48 Closure team, ${ }^{1,2}$ corrosion tests were conducted to determine the effects of the conventional Fenton's process on waste tank steel (i.e., Experiments 1-24 described within this report). Similarly, NETL ${ }^{3,4}$ funded work to examine the corrosion using a modified Fenton's process using TAML $^{\circledR}$, a proprietary reagent developed by researchers at Carnegie Mellon University. (This later scope consists of Experiments 25-31 described within this report.) The primary wall of Tank 48 is constructed of ASTM A537 class 1 carbon steel and the cooling coils of ASTM A106 carbon steel. Only A537 steel was studied in the present tests. The test solutions contained either ferric ion ${ }^{2,3}$ or tetraamido macrocylcic ligand. ${ }^{3,4}$ The objectives of the testing were to evaluate general corrosion rates and to determine the susceptibility of the steel to pitting corrosion. Standard short-term (up to 5 hours) electrochemical test methods were used. The original test matrix was described in the task technical plan SRT-MTS-2003-50017, “Corrosion Study for KTPB Destruction with Fenton's Reagent."

\section{EXPERIMENTAL}

The experiments employed the electrochemical test techniques of (1) linear polarization resistance (LPR) for measurement of the general or uniform corrosion rate and (2) cyclic potentiodynamic polarization (CPP) for assessment of pitting susceptibility. LPR subjects a test specimen to a small applied potential up to $15 \mathrm{mV}$ and measures the current response. The ratio of the voltage to the current yields the "polarization resistance," which is proportional to the corrosion rate. CPP scans apply relatively larger potentials up to $1 \mathrm{~V}$ to explore the onset of passivity (establishment of a protective oxide film) and its breakdown, the latter signaling the initiation of pitting corrosion.

The tests were performed on standard (0.63-inch diameter) specimens of ASTM A537 carbon steel in a simulated Tank 48 waste solution. Specimen discs (0.62 in. in diameter, 0.12 in. in thickness) were obtained from Metal Samples Co., Munford AL. Each specimen was fixed in a metallurgical mounting compound and polished to an 800-grit finish before immersion in the test solution. Figure 1 shows two mounted specimens in their glass holders.

A bulk quantity of solution of the recipe shown in Table 1 was provided by the Waste Processing Technology Section. Additional catalyst components that were added before testing are shown in the Appendix. A given test used 450 grams (approximately $400 \mathrm{~mL}$ ) 
of simulant; the $\mathrm{pH}$ was adjusted to initial values of 7,9 , or 11 with concentrated (69.6 weight \%) reagent grade nitric acid. Approximately 100 grams of 50 weight \%

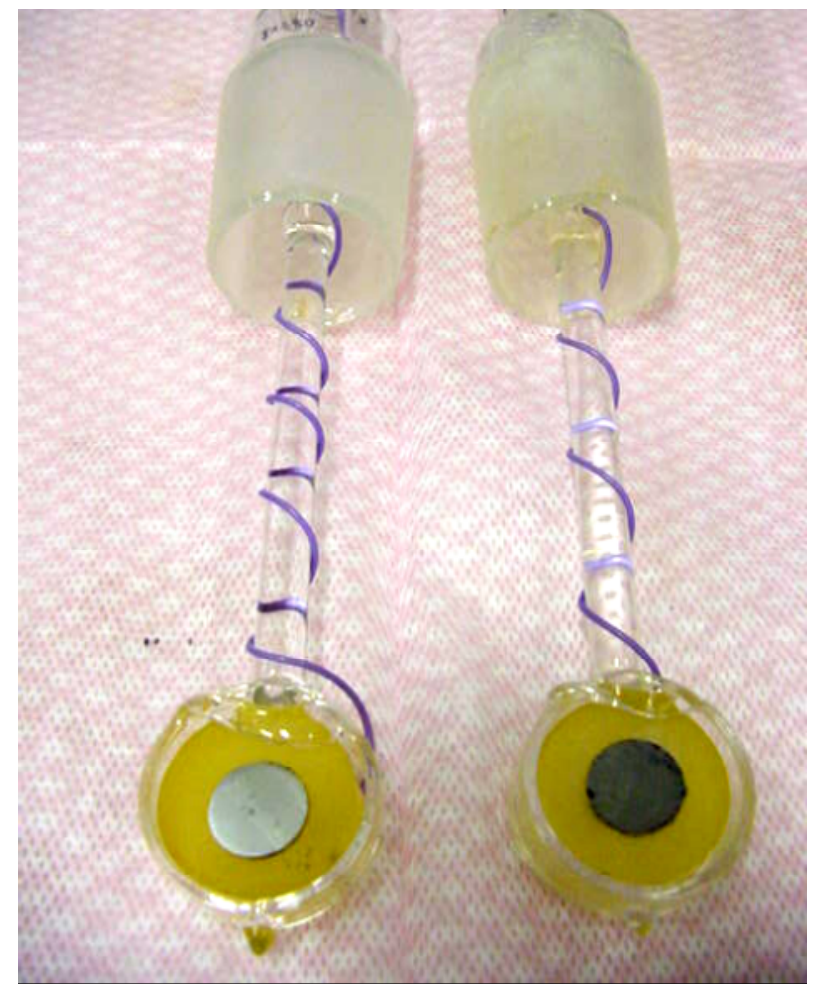

Figure 1. Mounted ASTM A537 Class 1 specimens in glass holders.

hydrogen peroxide (representing a stoichiometric ratio of about 1.5 to the available organic carbon) was added after pH adjustment. Either 500 ppm of ferric nitrate or 68.6 ppm tetraamido macrocylcic ligand $\left(\mathrm{TAML}^{\circledR}\right)$ were added as the principal catalyst. In the ferric nitrate tests, the entire ferric nitrate mass was added before $\mathrm{pH}$ adjustment. The hydrogen peroxide solution was added in two equal portions, one at the beginning of the test sequence and one just before the cyclic potentiodynamic polarization scan. In two instances ferric ion containing solutions were tested without hydrogen peroxide to measure a baseline corrosion rate without tetraphenylborate destruction. In the TAML ${ }^{\circledR}$ tests, one quarter of the peroxide and one fifth of the TAML ${ }^{\circledR}$ were added at specific points during the test (see description of the sequences of test steps below).

The Tank 48 simulant recipe has an initial total nitrate concentration of $0.353 \mathrm{M}$, which is in the concentration range (nitrate $<1 \mathrm{M}$ ) where pitting is the corrosion mode of concern. Pitting is prevented in SRS waste tanks by either (1) a minimum nitrite concentration that depends upon the nitrate concentration or (2) a minimum hydroxide concentration of 1 M. (The present hydroxide concentration in Tank 48 is 1.84 M.) Under neutralization by nitric acid, the nitrate concentration in the test solution rises to about $1.7 \mathrm{M}$, and the hydroxide concentration is decreased to $0.001 \mathrm{M}$ or less. Although the nitrate concentration is no longer in the dilute range, the present corrosion tests addressed 
Table 1. Tank 48H Simulant Recipe

\begin{tabular}{|l|c|}
\hline \multicolumn{1}{|c|}{ Component } & Concentration M \\
\hline $\mathrm{NaTPB}$ & 0.0728 \\
$\mathrm{NaOH}$ & 1.8425 \\
$\mathrm{NaNO}_{2}$ & 0.4709 \\
$\mathrm{NaNO}_{3}$ & 0.2753 \\
$\mathrm{Na}_{2} \mathrm{CO}_{3}$ & 0.1295 \\
$\mathrm{NaAlO}_{2}$ & 0.1118 \\
$\mathrm{Na}_{2} \mathrm{SO}_{4}$ & 0.0071 \\
$\mathrm{Na}_{3} \mathrm{PO}_{4}$ & 0.0077 \\
$\mathrm{NaCl}$ & 0.0088 \\
$\mathrm{NaF}$ & 0.0059 \\
$\mathrm{KNO}_{3}$ & 0.0779 \\
\hline
\end{tabular}

general corrosion and pitting because of the overall dilute condition of the Tank 48 simulant. The nitrite concentration of $0.4709 \mathrm{M}$ is not sufficient to prevent pitting under these conditions, and so pitting corrosion is expected.

Electrochemical measurements were made with a Princeton Applied Research model 273 computer-controlled potentiostat. Scribner Associates Inc. CORRWARE ${ }^{\circledR}$ software was used to control the potentiostat. The tests were performed in a 1-liter Greene cell (multinecked spherical flask, Figure 2) equipped with a condenser and two graphite counter electrodes. The reference electrode was electrically connected to the test solution through a water-cooled salt-bridge. The cell was placed on a temperature-controlled hot plate.

The sequence for the ferric ion tests consisted of:

1. Stabilization (record open-circuit potential) for one hour

2. First LPR measurement of corrosion rate

3. Stabilization (record open-circuit potential)for 0.5 hour

4. Second LPR measurement of corrosion rate

5. Addition of $2^{\text {nd }}$ hydrogen peroxide portion and stabilization for 0.5 hour

6. Third LPR measurement of corrosion rate

7. CPP measurement

The sequence for the TAML ${ }^{\circledR}$ tests was:

1. Add $25 \mathrm{~mL}$ of peroxide and $8 \mathrm{mg}$ of $\mathrm{TAML}^{\circledR}$ Stabilization (record open-circuit potential) for one hour

2. Add $25 \mathrm{~mL}$ of peroxide and $8 \mathrm{mg}$ of TAML ${ }^{\circledR}$ First LPR measurement of corrosion rate

3. Add $25 \mathrm{~mL}$ of peroxide and $8 \mathrm{mg}$ of $\mathrm{TAML}^{\circledR}$ 
Second LPR measurement of corrosion rate

4. Add $25 \mathrm{~mL}$ of peroxide and $8 \mathrm{mg}$ of TAML $^{\circledR}$ Stabilization for 0.5 hour

5. Third LPR measurement of corrosion rate

6. Add $8 \mathrm{mg}$ of TAML $^{\circledR}$

CPP measurement

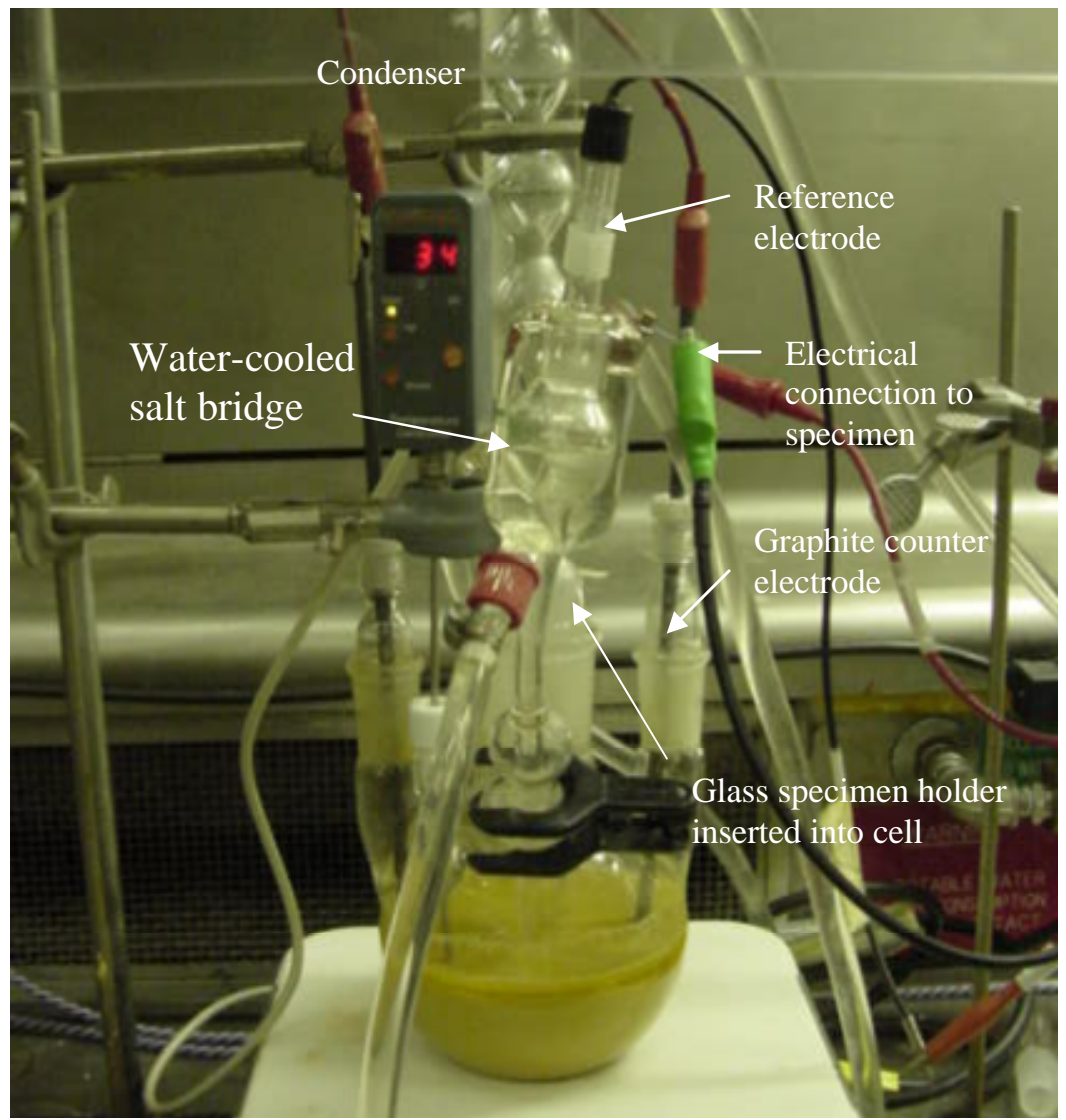

Figure 2. Greene cell containing test solution and immersed specimen on a temperature-controlled hot plate.

During stabilization periods the open-circuit potential (OCP) was recorded versus time. The OCP is the potential measured between the specimen and a reference electrode when there is no net current flow from the specimen. The reference electrode for all measurements was a saturated calomel electrode, which was water-cooled during testing. In the LPR test the specimen is subjected to a potential that is varied from $15 \mathrm{mV}$ below the OCP up to $15 \mathrm{mV}$ above the OCP and back to $15 \mathrm{mV}$ below, at a rate of $0.2 \mathrm{mV} / \mathrm{sec}$. The ratio of the change in applied potential $\bullet E$ to the change in current density response

- I is the "polarization resistance" $\mathrm{R}_{\mathrm{p}}$, which can be related to the corrosion rate:

$$
\mathrm{R}_{\mathrm{p}}=\cdot \mathrm{E} / \cdot \mathrm{I}=\mathrm{B} / \mathrm{I}_{\text {corr }} \text { as } \mathrm{I} \rightarrow 0
$$


where B is an empirical constant that can be related to the anodic and cathodic Tafel slopes and $\mathrm{I}_{\text {corr }}$ is the corrosion current. Here $\mathrm{B}$ is assigned the value $26 \mathrm{mV}$. The small voltage deviation from OCP is intended to maintain near-equilibrium conditions.

The CPP measurement consisted of a scan of the specimen applied potential from $50 \mathrm{mV}$ below the OCP to $1000 \mathrm{mV}$ above the OCP and back to the OCP. The potential scan rate was $0.2 \mathrm{mV} / \mathrm{sec}$. This non-equilibrium technique reveals the breakdown of a passive film that may form on the specimen, and the subsequent irreversible dissolution (corrosion) of metal at holes in the passive film. A current density higher on the reverse scan compared to that of the forward scan (termed negative hysteresis) indicates pitting (Figure 3). The specimens themselves were examined microscopically also for the presence of corrosion pits.

\section{RESULTS}

The results of the tests with ferric ion in the solution and those with $\mathrm{TAML}^{\circledR}$ are discussed separately in this section.

\section{Tests with Ferric Ion}

Table 3 lists the test parameters, the average general corrosion rate, and the qualitative assessment of localized corrosion (pitting) for the corrosion tests with ferric ion. The average corrosion rate was determined in most cases from the results of three linear polarization resistance measurements. The general corrosion rate tended to decrease with increasing $\mathrm{pH}$. Figure 4 shows the corrosion rate calculated from each individual LPR test versus the final $\mathrm{pH}$ of the test solution in which the test was run. General corrosion rates ranged from 1.0 to more than 100 mils per year $(0.01$ to 0.1 inch per year) at $\mathrm{pH}<8$ and from 10 down to less than 0.5 mils per year at $\mathrm{pH}>8$. At $\mathrm{pH}>10$ the corrosion rates were below 5 mils per year.

The Greene cells used in these tests were not equipped with cooling, and as a result of the heat generated in the acid neutralization and peroxide addition, the intended temperatures were usually exceeded. The temperatures typically fell in the range of 45 to $60^{\circ} \mathrm{C}$. Given the narrow range of temperatures across all tests and the variation in temperature during particular tests, temperature was not considered a meaningful parameter in interpreting the results. The intended initial pHs of 7 and 11 were attained more successfully than the intended temperature. However, chemical reactions during the tests usually raised to about 8 the $\mathrm{pH}$ of those solutions with an initial $\mathrm{pH}$ of 7 and lowered to about 10 the $\mathrm{pH}$ of those solutions starting at $\mathrm{pH} 11$.

Pitting may be revealed through the response of the current density to the applied voltage in CPP test as well through microscopic examination of the test specimen. Pitting usually occurs only when the specimen first develops an oxide layer that initially resists further corrosion (passive layer) but then breaks down in particular locations. Specimens that readily corrode in a general or uniform manner do not develop a passive layer and so tend not to show pitting. Figure 3 shows a CPP scan obtained at $\mathrm{pH} 11$ and $62^{\circ} \mathrm{C}$. The specimen of Figure 3 initially passivated as indicated in the low current density $\left(<10^{-5}\right.$ 
amps $/ \mathrm{cm}^{2}$ ) of the forward scan. The characteristic of a much higher current density in the reverse scan compared to that of the forward scan (negative hysteresis) indicates pitting corrosion. Numerous small pits were observed microscopically on this specimen, as they were on other specimens reported in Table 3. A pH of 7 is expected to be more corrosive to carbon steel than a $\mathrm{pH}$ of 11 . Table 3 shows that pitting was observed in all but two of the $\mathrm{pH} 7$ tests. In those two tests the CPP scans showed no passivity and high current densities, indicating general corrosion. The general corrosion rates from these two tests were an order of magnitude greater than the other $\mathrm{pH} 7$ tests.

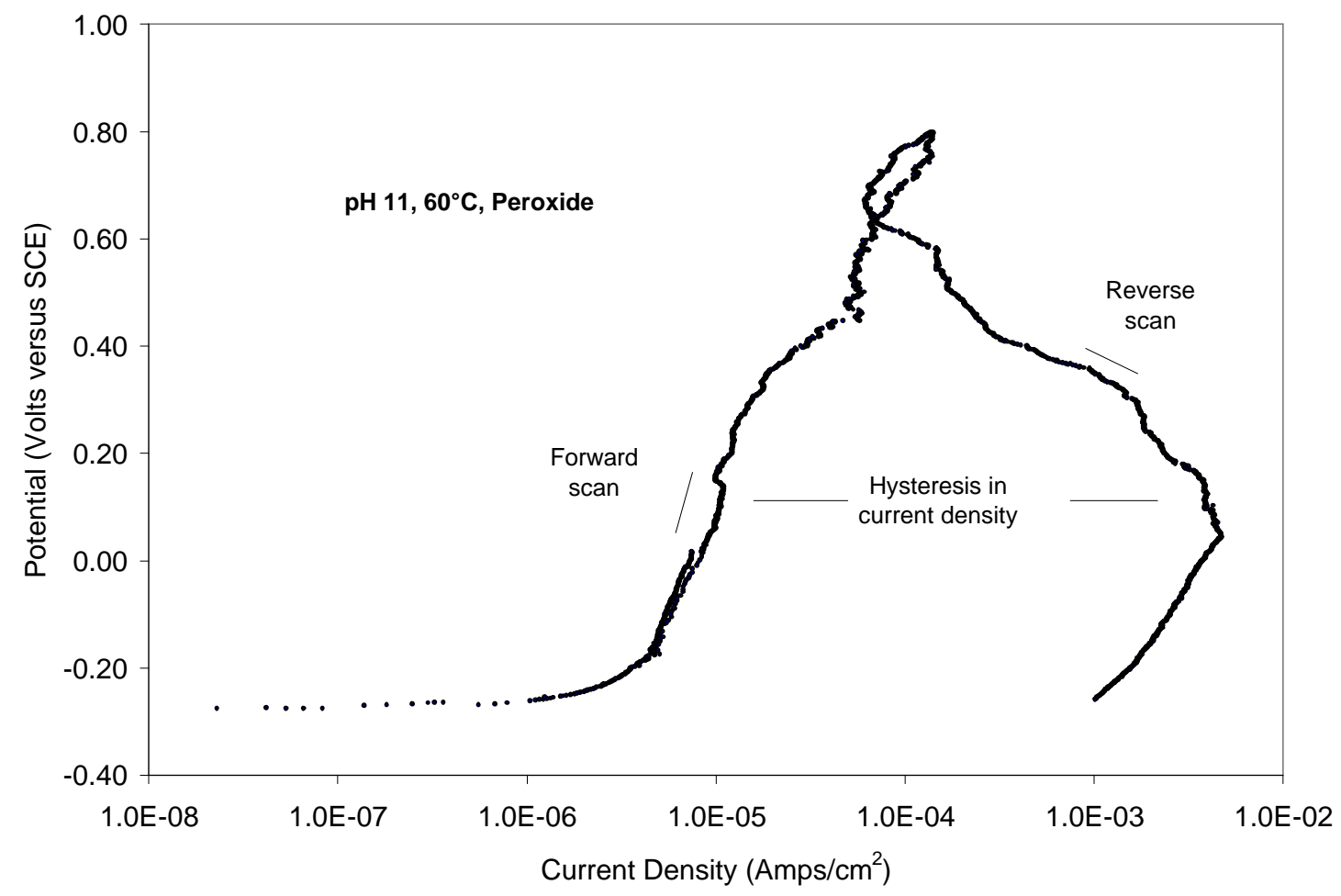

Figure 3. Example of a CPP scan showing a large negative hysteresis in the current density. 


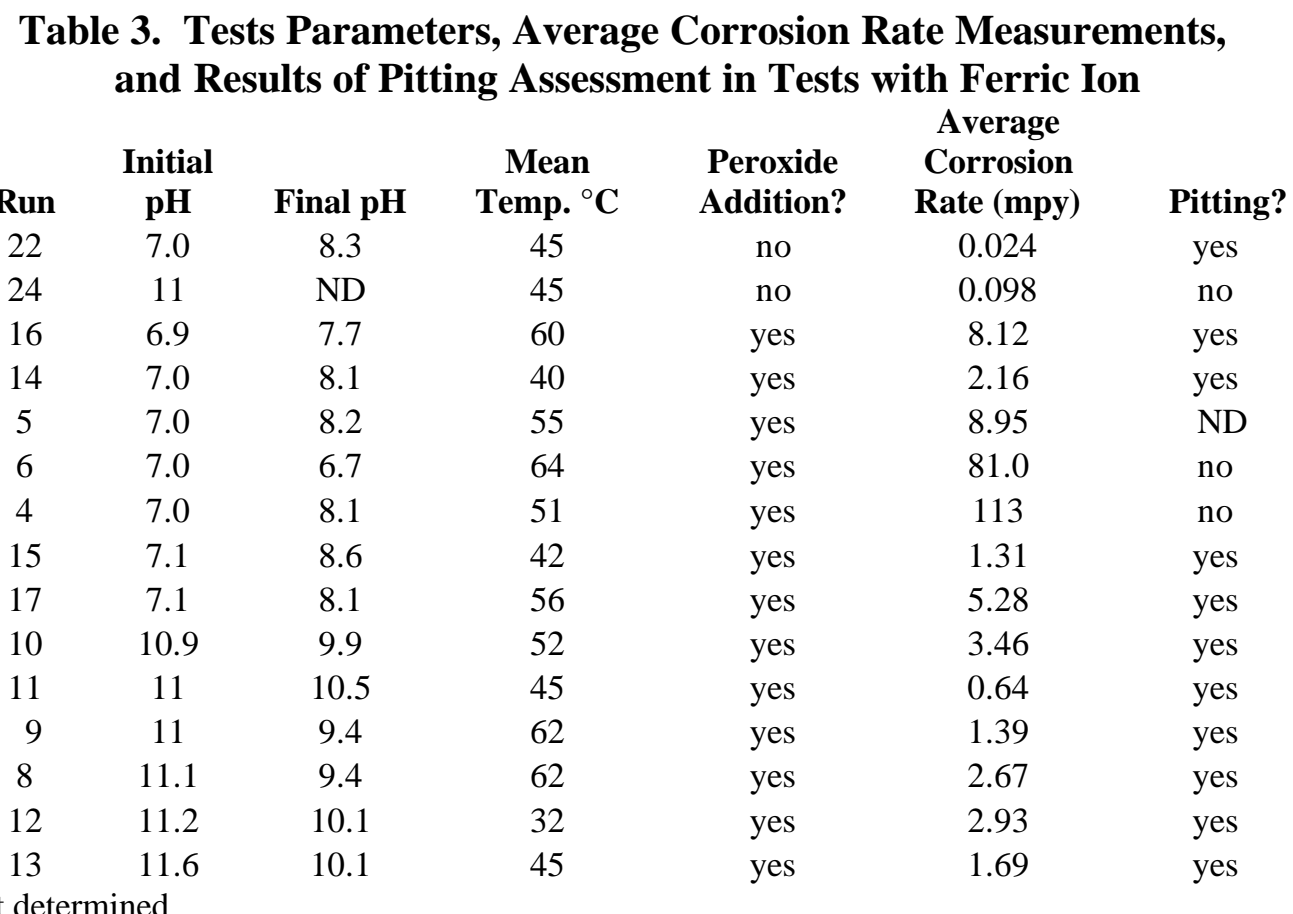

$\mathrm{ND}=$ not determined

Runs 22 and 24 at $45^{\circ} \mathrm{C}$ were tests without hydrogen peroxide. The sodium tetraphenylborate was therefore not decomposed. Very low corrosion rates of 0.024 mils per year at $\mathrm{pH} 7$ with pitting and 0.098 at $\mathrm{pH} 11$ without pitting were recorded in these runs.

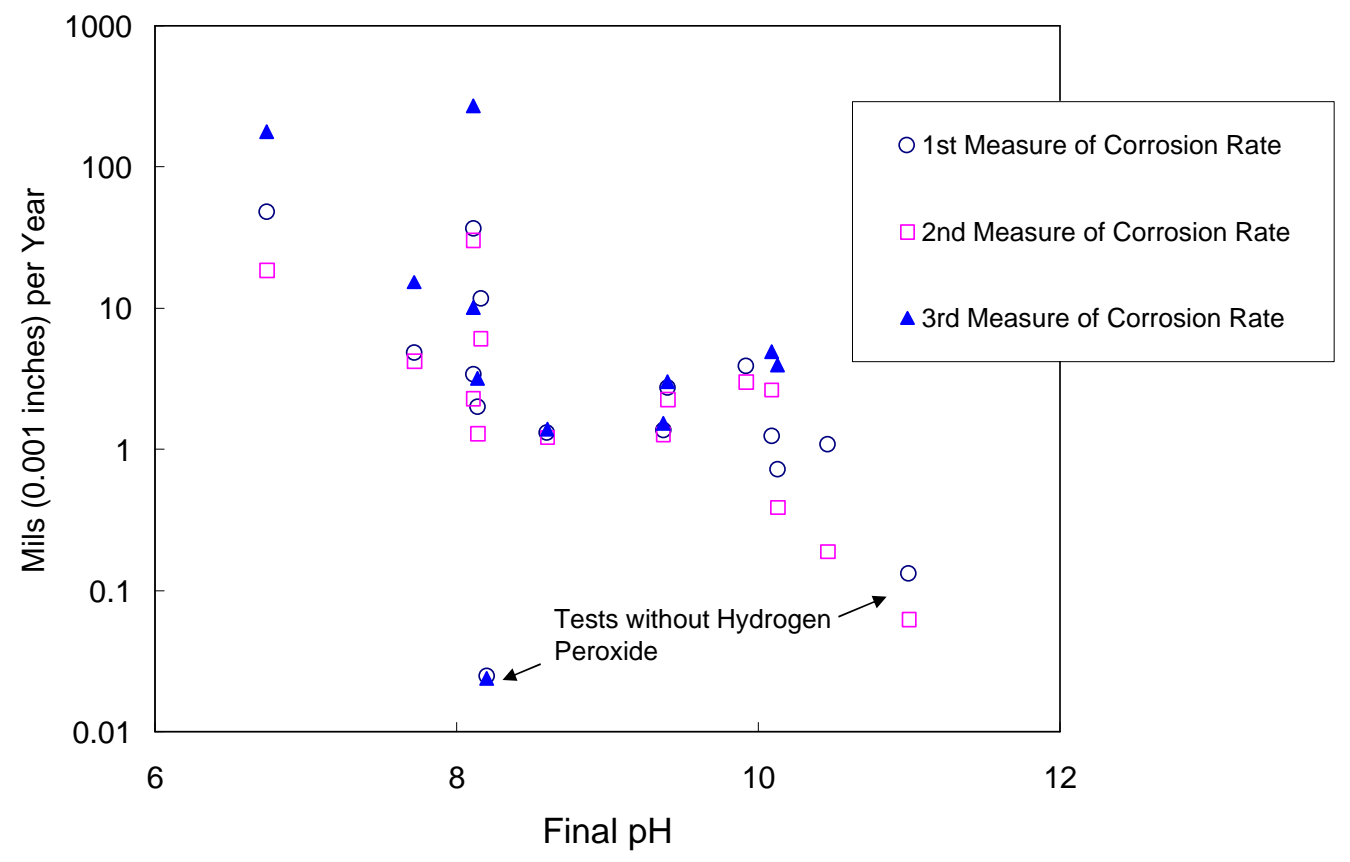

Figure 4. General corrosion rates calculated from LPR measurements versus final $\mathrm{pH}$ in the ferric ion containing tests. 


\section{Tests with TAML ${ }^{\circledR}$}

Table 4 lists parameters and results for the seven tests in solutions containing the catalyst TAML $^{\circledR}$. These tests were done at either an initial $\mathrm{pH}$ of 9 or of 11 , and the $\mathrm{pH}$ declined about one unit during the course of the test. Intended test temperatures were 45 or $60^{\circ} \mathrm{C}$, and the same variation in temperature occurred in these as in the ferric ion tests. The average corrosion rates ranged from 2.1 mils per year ( 0.0021 inches per year) in an initial $\mathrm{pH} 9$ solution at $43^{\circ} \mathrm{C}$ to 20 mils per year $\left(0.020\right.$ inches per year) in $\mathrm{pH} 9$ at $60^{\circ} \mathrm{C}$. As the complete set of LPR measurement of corrosion rates shows (Figure 5), the higher corrosion rates occurred at $\mathrm{pH} 9$ and the lower at 11, similar to the ferric ion tests. (The same scales are used in Figures 4 and 5 to facilitate comparison.) Not all LPR measurements were successful, so that three measurements were not recorded for each run. When the third LPR measurement (after the fourth TAML ${ }^{\circledR}$ addition to the test solution) was successful, the resulting corrosion rate was lower than those in the first two measurements, as Figure 5 shows. This trend suggests that the simulated waste becomes less corrosive with tetraphenylborate destruction, despite the $\mathrm{pH}$ decline to presumably more aggressive values. All specimens developed small corrosion pits during the tests, although not all cyclic potentiodynamic polarization scans showed the normally characteristic negative hysteresis.

\begin{tabular}{|c|c|c|c|c|c|c|}
\hline Run & $\begin{array}{c}\text { Initial } \\
\text { pH }\end{array}$ & Final pH & $\begin{array}{c}\text { Mean } \\
\text { Temp. }{ }^{\circ} \mathrm{C}\end{array}$ & $\begin{array}{c}\text { Peroxide } \\
\text { Addition? }\end{array}$ & $\begin{array}{c}\text { Average } \\
\text { Corrosion } \\
\text { Rate (mpy) }\end{array}$ & Pitting? \\
\hline 30 & 9.0 & 8.2 & 60 & yes & 14 & yes \\
\hline 28 & 9.0 & 8.4 & 43 & yes & 2.1 & yes \\
\hline 29 & 9.0 & 8.2 & 60 & yes & 20 & yes \\
\hline 27 & 9.0 & 8.2 & 45 & yes & ND & yes \\
\hline 31 & 10.9 & 9.4 & 62 & yes & 3.6 & yes \\
\hline 26 & 10.9 & 9.8 & 47 & yes & 3.9 & yes \\
\hline 25 & 11.0 & ND & 54 & yes & 5.1 & yes \\
\hline
\end{tabular}




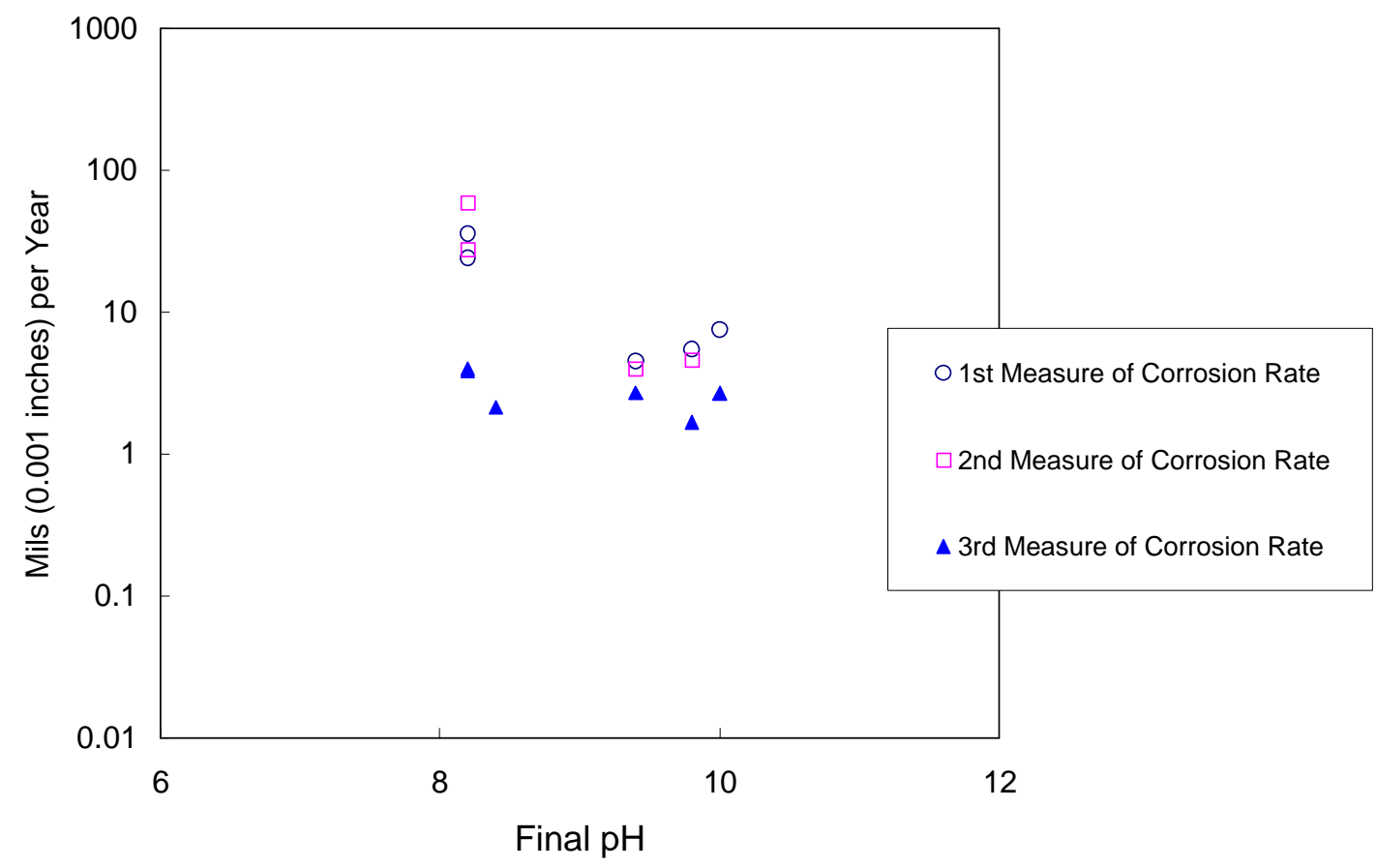

Figure 5. General corrosion rates calculated from LPR measurements versus final $\mathrm{pH}$ in the $\mathrm{TAML}^{\circledR}$ containing tests.

\section{CONCLUSIONS}

Corrosion tests of waste tank carbon steel (ASTM A537 class 1) in a Tank 48 simulated waste containing hydrogen peroxide and ferric ion (Fenton's reagent) showed that relatively high general corrosion rates of 1.31 to 113 mils per year could occur when the waste was at $\mathrm{pH} 7$ to 8 . However, the general corrosion rate was 0.64 to 3.6 mils per year under $\mathrm{pH} 10$ to 11 conditions. Localized corrosion or pitting was observed on all specimens but two of the $\mathrm{pH} 7$ test conditions. The pitting was not quantified in the present tests. These results were recorded at temperatures from 32 to $65^{\circ} \mathrm{C}$, but the temperature during a test run was not well controlled due to heats of neutralization and reaction.

In the tests with $\mathrm{TAML}^{\circledR}$ catalyst present in place of ferric ion, three tests were completed at $\mathrm{pH} 11$ and four at $\mathrm{pH}$ 9. The $\mathrm{pH} 11$ tests produced general corrosion rates in individual LPR tests of 1.7 to 7.6 mils per year ( 0.0017 to 0.0076 inches per year), similar to those measured with ferric ion at $\mathrm{pH} 11$. At $\mathrm{pH} 9$ the general corrosion rates ranged from 2.1 to 36 mils per year. Pitting was observed also in these tests.

The corrosion rates in the $\mathrm{pH} 11$ solutions would produce metal losses of less than 3 mils in a prospective four-month-long destruction process. Such wall-thinning would not significantly affect the structural integrity of the waste tank and would be well below reportable values. The threshold for reporting wall-thinning in the in-service inspection program for high-level waste tanks is $10 \%$ of wall thickness (e.g. 50 mils' loss in 0.5 - 
inch-thick plate). The 3-mil loss would also not significantly affect the cooling coils, whose wall thickness is about 150 mils.

The susceptibility to pitting that is reported here cannot be quantified with the present testing. The number of pits per unit area and the maximum depth of pitting after a particular exposure must be determined with coupon testing. Because of the random distribution of pit growth rates and ultimate depths, inhibitor concentrations cannot be readily developed that limit pitting to a particular severity. It is known from laboratory experiments that uninhibited waste solutions at $\mathrm{pH} 9.7$ yield pits that may grow at a rate of the order of 50 mils per year. ${ }^{6}$ This rate may appear tolerable for periods of time much less than one year. The pits, however, may become effectively immune to arrest by the restoration of high inhibitor concentrations. They may continue to grow if they have been covered by corrosion products. The pitting seen in the $\mathrm{pH} 11$ Fenton's tests should be far less severe than that seen in reference 6. Coupon immersion tests can reveal the expected severity of the pitting and provide a technical basis for an engineering judgment of the risk of extreme pitting under a Fenton's reagent process.

The chemistry control program specifies minimum nitrite and/or hydroxide concentrations to prevent pitting. The nitrite concentration limit depends exponentially upon temperature, and temperatures above $50^{\circ} \mathrm{C}$ lead to nitrite concentrations that are prohibitively costly. Chemical alternatives to nitrite, such as molybdate and phosphate, have been investigated and found to inhibit pitting, but their concentrations were not compatible with the vitrification processes. Pitting can be prevented by cathodic protection systems, as is done for the carbon steel jacket of an SRS waste transfer line. Its use in the internal configuration of a waste tank with its cooling coils is considered impractical due to the limited number of risers and the likelihood of the electrical shielding of some components or areas by others, leading to corrosion of the shielded areas.

\section{RECOMMENDATIONS}

These experiments indicate that a tetraphenylborate decomposition process based on Fenton's reagent may not be excessively corrosive if performed at $\mathrm{pH} 11$. However, the LPR tests were performed under conditions that were not always at chemical equilibrium, as a result of the periodic additions of hydrogen peroxide and, in the case of the second set of tests, the TAML ${ }^{\circledR}$ catalyst. To confirm these initial short-term electrochemical test results long-term (50 and 100 days' duration) coupon immersion tests are recommended. As stated above, coupon tests provide the means of quantifying the pitting susceptibility and in particular the deepest pits expected under worst-case conditions. The coupon tests, which should simulate the expected process, may also be used to determine longerterm effects of the process on waste tank steel.

\section{REFERENCES}

1. TTR No. HLE-TTR-2003-101, "In-Tank Fenton's Destruction of Tank 48 Simulant, April 3, 2003. 
2. WSRC-RP-2003-00396, "Task Technical and Quality Assurance Plan for Destruction of Tetraphenylborate in Tank 48H," May 27, 2003.

3. D. P. Lambert, P. A. Taylor, T. B. Peters, M. J. Barnes, and S. D. Fink, "Task Technical and Quality Assurance Plan for NETL Fenton Destruction of Tetraphenylborate in Tank 48H," WSRC-RP-2003-00410, June 10, 2003.

4. D. P. Lambert, T. B. Peters, M. J. Barnes, and P. A. Taylor, "Fenton Destruction of Tetraphenylborate in SRS Tank 48H," WSRC-SRTC-PR-03-021-01, February 7, 2003.

5. SRT-MTS-2003-50017, "Task Technical Plan Corrosion Study for KTPB Destruction with Fenton's Reagent," June 10, 2003.

6. P. E. Zapp, "Pitting Growth Rate in Carbon Steel Exposed to Simulated Radioactive Waste," paper no. 129, CORROSION/96, NACE International, Houston TX, 1996. 
Appendix A

Catalyst Components

\begin{tabular}{|c|c|c|}
\hline $\begin{array}{c}\text { Component } \\
\text { Name }\end{array}$ & Compound(s) & $\begin{array}{c}\text { Species } \\
\text { Concentration } \\
\text { in } 4.7 \mathrm{M} \mathrm{Na}^{+} \\
\text {Slurry }(\mathrm{mg} / \mathrm{L})\end{array}$ \\
\hline $\mathrm{Pd}$ & $\mathrm{Pd}\left(\mathrm{NO}_{3}\right)_{2}$ & 13 \\
\hline $\mathrm{Cu}$ & $\mathrm{Cu}\left(\mathrm{SO}_{4}\right) \bullet 5 \mathrm{H}_{2} \mathrm{O}$ & 3.7 \\
\hline \multirow{5}{*}{$\mathrm{Mo} / \mathrm{Cr} / \mathrm{Si} / \mathrm{Se} / \mathrm{As}$} & $\mathrm{Na}_{2} \mathrm{MoO}_{4} \cdot 2 \mathrm{H}_{2} \mathrm{O}$ & 12 \\
\hline & $\mathrm{Na}_{2} \mathrm{CrO}_{4}$ & 60 \\
\hline & $\mathrm{Na}_{2} \mathrm{SiO}_{3} \bullet 9 \mathrm{H}_{2} \mathrm{O}$ & 16 \\
\hline & $\mathrm{Na}_{2} \mathrm{SeO}_{4}$ & 1 \\
\hline & $\mathrm{As}_{2} \mathrm{O}_{3}$ & 0.04 \\
\hline \multirow{3}{*}{$\mathrm{Zn} / \mathrm{Pb} / \mathrm{Fe}$} & $\mathrm{Zn}\left(\mathrm{NO}_{3}\right)_{2} \bullet 4 \mathrm{H}_{2} \mathrm{O}$ & 8.8 \\
\hline & $\mathrm{Pb}\left(\mathrm{NO}_{3}\right)_{2}$ & 1.2 \\
\hline & $\mathrm{Fe}\left(\mathrm{NO}_{3}\right)_{3} \bullet 9 \mathrm{H}_{2} \mathrm{O}$ & 2.6 \\
\hline $\mathrm{Sn}$ & $\mathrm{SnCl}_{2}$ & 2.1 \\
\hline \multirow{3}{*}{$\mathrm{Ca} / \mathrm{La} / \mathrm{Co}$} & $\mathrm{Ca}\left(\mathrm{NO}_{3}\right)_{2} \bullet 4 \mathrm{H}_{2} \mathrm{O}$ & 12.2 \\
\hline & $\mathrm{La}\left(\mathrm{NO}_{3}\right)_{3} \bullet 6 \mathrm{H}_{2} \mathrm{O}$ & 0.05 \\
\hline & $\mathrm{Co}\left(\mathrm{NO}_{3}\right) 2 \bullet 6 \mathrm{H}_{2} \mathrm{O}$ & 0.04 \\
\hline \multirow{2}{*}{$\mathrm{Cd} / \mathrm{Ce}$} & $\mathrm{Cd}\left(\mathrm{NO}_{3}\right)_{2} \bullet 4 \mathrm{H}_{2} \mathrm{O}$ & 0.4 \\
\hline & $\mathrm{Ce}\left(\mathrm{NO}_{3}\right)_{3} \bullet 6 \mathrm{H}_{2} \mathrm{O}$ & 0.3 \\
\hline $\mathrm{Rh}$ & $\mathrm{Rh}\left(\mathrm{NO}_{3}\right)_{3}$ & 1.4 \\
\hline $\mathrm{Ag}$ & $\mathrm{AgNO}_{3}$ & 6.8 \\
\hline $\mathrm{Ru}$ & $\mathrm{RuCl}_{3} \bullet \mathrm{xH}_{2} \mathrm{O}$ & 5.4 \\
\hline $\mathrm{Hg}$ & $\mathrm{Hg}\left(\mathrm{NO}_{3}\right)_{2} \bullet \mathrm{H}_{2} \mathrm{O}$ & 2.2 \\
\hline diphenylmercury & $\left(\mathrm{C}_{6} \mathrm{H}_{5}\right)_{2} \mathrm{Hg}$ & 150 \\
\hline sludge $^{\mathrm{a}}$ & Sludge & 500 \\
\hline $\mathrm{MST}^{\mathrm{a}}$ & MST & 500 \\
\hline $\mathrm{Fe}$ & $\mathrm{Fe}\left(\mathrm{NO}_{3}\right)_{3} \bullet 9 \mathrm{H}_{2} \mathrm{O}$ & 500 \\
\hline TAML $^{\circledR}$ & & 68.6 \\
\hline
\end{tabular}

${ }^{a}$ Note that MST and sludge were added at concentrations well below the Tank $48 \mathrm{H}$ simulant target. In these experiments, MST and Sludge should have been added at 0.2 wt \% based on the solids present in the MST and Sludge slurries. In these experiments, the MST and sludge were added at a $500 \mathrm{mg} / \mathrm{L}$ on a slurry basis. As a result, the sludge and MST were under-added by a factor of $\sim 40 \mathrm{X}$. The concentrations of the important aqueous ions nitrate, nitrite, sulfate, chloride and hydroxide will not significantly change by increasing the MST and sludge solids. These anions are the species participating in the corrosion reactions, along with dissolved oxygen. The insoluble solids (sludge and MST) were filtered out in the corrosion control testing during the 1980's and 1990's (data was used to develop the corrosion controls for pitting prevention). It is unlikely that this mistake in the recipe had any impact on the corrosion testing. 